\title{
THE CONTRIBUTIONS OF NEUROPSYCHOPEDAGOGISM IN THE SCHOOL CONTEXT: IN THE REHABILITATION OF CHILDREN WITH LEARNING DISABILITIES IN BASIC EDUCATION
}

\author{
Elizabete Barbosa da Silva ${ }^{1}$ \\ Maria Aparecida Barbosa de Sousa ${ }^{2}$ \\ Mónica Cristina Reis dos Santos ${ }^{3}$ \\ Cybelle Maria de Souza Santos ${ }^{4}$ \\ Gesyanne de Souza Monteiro ${ }^{5}$ \\ Diogenes José Gusmão Coutinho ${ }^{6}$
}

\begin{abstract}
RESUMO: O presente estudo buscou apresentar a importância do Neuropsicopedagogo no Contexto Escolar: na Reabilitação de Crianças com Déficit de Aprendizagem na Educação Básica. Promovendo uma reflexão sobre a atuação e as contribuições Neuropsicopedagógicas no campo escolar. Por meio de uma revisão de cunho científico, qualitativa, bibliográfico de livros, artigos e documentos publicados por teóricos como: FARRELL (2008), FONSECA (2014); NIETO (2014). Logo, o presente estudo refere-se através de uma revisão bibliográfica apresentar As Contribuições dos Colaboradores; SAMPAIO (2017), VYGOTSKY apud FONTES (2003) e outros. Desta forma conclui-se que fazer a reabilitação de crianças com déficit de aprendizagem pode ser um trabalho mais gratificante ou mais frustrante de todos. Os resultados alcançados fazem com que o profissional se torne um agente de mudança. Por outro lado, se o trabalho for consistente e bom o profissional da educação precisará lidar e compreender que os constrangimentos serão inevitáveis. Pra tanto esta pesquisa pretende contribuir na construção de ações com maiores possibilidades de acertos.
\end{abstract}

Palavras-chave: Aprendizagem. Déficit. Reabilitação.

ABSTRACT: Neuropsychopedagogue in the School Context: in the Rehabilitation of Children with Learning Deficit in Basic Education. Promoting a reflection on the performance and neuropsychopedagogic contributions in the school field. Through a scientific, qualitative, bibliographic review of books, articles and documents published by theorists such as FARRELL (2008), FONSECA (2014); NIETO (2014) and The present study sought through a bibliographic review to preseent The Contributions of Collaborators; SAMPAIO (2017), VYGOTSKY apud FONTES (2003) and others. Thus, it is concluded that rehabilitation of children with learning disabilities can be a more rewarding or more frustrating job of all. The results achieved make the professional become an agent of change. On the other hand, if the work is consistent and good, the professional education will have to deal with and understand that disappointments and constraints will be inevitable. For this purpose, this research intends to contribute to the construction of actions with greater possibilities of correct answers.

Keywords: Learning. Deficit. Rehabilitation. Rehabilitation.

\footnotetext{
${ }^{\mathrm{I}}$ Licenciatura Em História E Pedagogia, Especialização Em Psicopedagogia, Supervisão E Orientação Escolar.

${ }^{2}$ Licenciatura Em Geografia E Pedagogia, Especialização Em Supervisão Escolar.

3 Licenciatura Em Pedagogia E Ciências Com Habilitação Em Matemática. Especialização Em Psicopedagogia Institucional E Pesquisa Avançada Em Educação.

${ }^{4}$ Licenciatura Em Letras, Especilização Em Supervisão Escolar.

${ }^{5}$ Licenciatura Em Letras, Especialização Em Língua Portuguesa E Ensino.

${ }^{6}$ Specialist in Special and Inclusive Education, PhD in Biology from UFPE. Teacher at Faculdade Alpha e Unibra - Brazilian University Center.
} 


\section{NTRODUCTION}

For the field of neuropsychopedagogy, focused on knowledge and principles related to studies between neurosciences, cognitive psychology and pedagogy it is understood that it has acquired space in Brazil arising as well as a new transdisciplinary science. With this emergence, higher education since 2008 began the first courses of Graduate Studies in Neuropsychopedagogy in the country, having as main applicability to list brain functions through human learning, in order to rehabilitate apprentices and prevent possible problems in students.

Faced with the various situations researchers such as: Pedagogues, Psychopedagogists, Psychologists, Neuropsychologists, Pediatricians, Occupational Therapists, Neuroscientists, Psychiatrists, Speech Therapists, joined and created strategies to understand the functioning of the brain in the cognitive and emotional processes of the individual, conceptualizing:

[...] neuropsychopedagogy seeks to bring together and integrate studies of the development, structures, functions and dysfunctions of the brain, while at the same time stupeising the psychocognitive processes responsible for learning and the psychopedagogical processes responsible for teaching" (FONSECA, 2014, p.I).

Based on this above, neuropsychopedagogy is characterized in the area of knowledge focused on learning as the main function to evaluate the individual through the difficulties existing inside and outside the Historical/Social, Cultural, Economic and Educational context associating the brain as a coupling of the whole system.

Within the educational context, neuropsychopedagogy has been presenting knowledge by aligning various behaviors and thoughts, so the professional is in charge of solving the "problem" interfered in the learning process. Theorists such as Nieto (2014), Sampaio (2014) and others say that: It is up to the neuropsychopedagogist to evaluate the cognitive needs of the student, so that there is a stimulating intervention and the possibility of understanding how learning development is processed, with differentiated activities for children with learning disabilities who need rehabilitation in the educational field respecting the pace of development of each student in daily life scholastic.Generalizing the learning deficit in basic education as one of the most 
challenging components for professionals working in clinics as well as those who work in school, presenting gaps in their emotional and neuropsychological aspect in which there is a strong influence on the education of any being.

In this sense, the study was characterized containing a bibliographic review; according to NIETO, (2014, p.32), learning is the process where skills, skills and behaviors are acquired and can be modified through stimuli, experience, training, reasoning and observation; in this way we emphasize that it is in learning where they are understood that they will flow by following and being transformed with each cycle where we direct learning to learn.

For Sampaio (2017), the subject may encounter obstacles, but they can be overcome as we find at school and in the subject himself a door that allows us to enter and (re) build together to these a new apprenticeship. In this sense, the apprentice gemwill only be possible torehabilitate by bringing new approaches and reflections inserted in the educational system in which the contribution of the professional is of paramount importance for the teaching of the student.

From the legal frameworks provided for in the Laws of Guidelines and Bases of National Education - LDB on no. 9,394/96 to ensure that the student is indispensable training providing means to progress, associating the other fight through law no. 5,289/16 is being sanctioned with the effective right in the processes of acquisition of learning or in its development is right as described above.

The methodology for the present study was based on a literature review that according to CERVO \& BERVIAN (1983, p.50), the research is focused on the solutionof problems, through the use of scientific processes, because, of a doubt or problem seeks solutions.

Thus, this study aimed to demonstrate the neuropsychopedagogical contributions in the school environment about the rehabilitation of children characterized with learning deficit in basic education. In its specifics, understand the learning process; evaluate the path of educational rehabilitation of the student and demonstrate the contributions of neuropsychopedagogy in the educational field. The process by the which the student was inserted under the gaze of a neuropsychopedagogist who come to evaluate and rehabilitate students through 
these difficulties.

Thus, the results and discussions based on the topics: Concept of Learning Deficit, The Importance and Contribuição of Neuroscience in the formation and practice of neuropsychopedagogue, The contributions of the neuropsychopedagogist in the school context: in the rehabilitation of children with learning disabilities in basic education, Methodology, Results and Discussions, Conclusion and References.

\section{THEORETICAL FOUNDATION}

\subsection{Learning Deficit}

The search for understanding the individual world of each child is continuous so that possibilities and opportunities for intellectual, educational, social, cultural and emotional development can be created in a full and healthy life in all aspects for the child or any other individual.

In this sense, when we talk about thedeficit of prendizing, we need to understand that: Learning difficulties, sometimes referred to as learning disorder or learning disorder, is a type of disorder by which the individual has difficulties in learning effectively.

Thisr ahead of the follow-up or treatment of a possible learner who presents learning deficit does not exempt us from the possibility of having some type of deficit. This placement is relevant by the history of professional evaluation errors inthe educational and health areas.

In terms of mental disorders with antecedent factors in childhood, neurodevelopmental disorders (Autism spectrum disorders, attention deficit/hyperactivity disorder (ADHD) are a chronic disease that causes aggressive behavior, anxiety, restlessness, among other. Learning difficulties, being linked to factors such as: the methodology used, pedagogical methods, the physical environment and even those related to the student himself and his/her life context. Specific learning disorders a different way of aprender, due to a barrier that can be cultural, cognitive or emotional etc).

in the field of neuropsychology and neurology such disorders are classified as mental functions associated with the brain. What for 
neuropsychopedagogy is understood as the search, understanding and performance for the improvement of students with special needs, and it is up to professionals and educators to search for systematized contents, and relevance for quality neurop sicopedagogical intervention in the school context, in the office and in inclusion in society. (FREITAS and SAMPAIO, 20I4, p.II)

Deficit, difficulty and learning disorder are aspects and reasons of many discussions referring us to the conceptual miscellany that often presents in students poor preparation, educators and professionals poorly qualified in a society even less prepared to understand, accept and include people who, despite being special, have potentials that need only to be identified, explored positively like Mozart who at only 4 years of age start his beautiful and renowned musical career, managing to memorize a song in just I hour and at six 6 begins to commake and at 8 already writes symphonies.

For this, it is necessary an interdisciplinary perspective that adds different specialties, with a convergent look at the target that is the student and the interventions to be carried out with the students their peculiarities and their needs.

To know is to enable transformation, Topczewski (200o); it states that learning can be translated as the ability and possibility that people have to perceive, know, understand and retain in memory the information obtained, just that knowledge is properly explored and able to reproduce significativamente the function of controlling movements, receiving and interpreting sensory stimuli, coordinating the acts of intelligence, memory, reasoning and imagination.

Thus, it is worth noting that for (MERCH apud MALUF) "The process of learning the offspring is understood as a multicausal process, comprehensive, implying components of various axes of structuring: affective, cognitive, motor, social, economic, and political". This means that, when we know learning as a process consisting of several factors, not being able to accept a single cause as a determinant for the difficulties related to it. (SAMPAIO 2014).

\subsubsection{Because the Crianças don't learn}

why don't the kids learn? For the educator this is a challenging issue for more effort, skill and commitment that the educator proposes children seem to be 
inside an impenetrable glass dome, where whoever is inside see the world outside turn and whoever is outside cannot penetrate and the search for a life with meaning is almost nonexistent.

Not learning may be linked to various factors, physical, economic, social, emotional, cultural, political, cognitive, psychological, neurological and family factors and situations. Learning difficulties encompass a heterogeneous group of problems that affect the possibility of the learning process happens in a healthy and natural way, regardless of its conditions.

According to Piaget there arefour periods of cognitive development known as: sensormotor, preoperative, concrete operative and formal surgery, following a necessary chronological sequence one after the other. Metring (2019). Understanding that each of these steps has its importancethe fundamental for the development of learning.

According to Castanhel apud Freitas and Sampaio (2014) We are far from completely discovering what is the nature of the learning processes of the human mind and, every day, one remakes and evaluates acquired knowledge in an attempt to at least understand. However, for Farrell (2008) there is an organic impairment, of neurologicalorchemical origin, such as psychological and neurological changes within the gestational, post-gestational and infant periods.

One of the aspects that hinder learning and does not allow the student to take advantage of its potentialis: family and social, where family participation in the learning process is fundamental. Weiss (2009). Family segregation and its new formations have contributed to the learning difficulties, in the social aspect, it is worth noting that children in situations of family segregation and economic difficulties, homosexual family formation, social vulnerability and disorders intellectuals are continually victims of often inmane prejudices.

Another significant aspect is that of educational policies that ensure in the form of laws and guidelines for basic education the guarantee of rights to access to educational, intellectual, social and cultural learning and development. However what you see is a reality far from the above, the absence of physical structure and professionals qualified for the exercise of educational functions. 
For Vygotsky (2003),

The emotional aspect of the individual has no less importance than the other aspects and is an object of concern in the same proportions in which it is intelligence and will. Love can become as much a talent as genius, as in the discovery of differential calculus. (p.r46)

Still Vygotsky, "The social formation of the mind", incorporated and directed the issue of learning to an aspect that would instill the relationship between learning and development the social aspect.

There is no learning meramente cognitive or rational, because a child who experiences problems in his family environment, sometimes can not abstract or concentrate as inverse also happens, a child who feels difficulty in learning can develop and when feeling low self-esteem, which translates into a negative image of himself can harm even more. The child who has family problems, has prevented their learning by feeling unable to develop their skills and abilities.

According to José \& Coelho (2002, p.23)

$[\ldots]$, there are numerous factors that can trigger problems or learning disorders; how:

- Organic factors - health, physical, deficiency, lack of neurological integrity (sick nervous system), inadequate nutrition and ct;

- Psychological factors - inhibition, fantasy, anxiety, anxiety, inadequacy to reality, generalized feeling of rejection and etc;

- Environmental factors - the type of family education, the degree of stimulation that the child received from the first days of life, the influence of the media and etc.

Also according to these authors, symptoms and behavior children present themselves with such intensity, that it is difficult for the professional whether health or education distinguish and identify why children do not learn? The educator facing this question only detects the difficulties requiring a psychopedagogical evaluation and even isin somecases neuropsychopedagogical

\subsection{The Importance and Contribution of Neuroscience in the Formation and Practice of Neuropsychopedagogue}

According to RELVAS(2017), "The educator must prepare to find his class diversified, adjusting the class work to allow the maximum development of the skills of each child". Thus, professional training is extremely and 


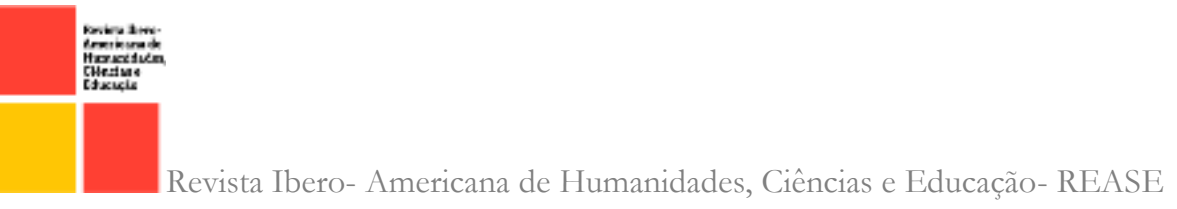

fundamental importance, being through a good training and specialization that the educator is qualified to offer a higher quality learning providing the student with a wide grid of opportunity and Possibilities.

The training and practice of the neuropedagogue assumes the role of an action not only in the school environment but also in the clinic, to the extentthat it helps to minimize the suffering of students who have already failed at school, through strategies and techniques learned throughout their training and specialization within the educational area in which neuroscience brings its contributions.

The contribution of neuroscience implies establishing interactions between the biological, anatomical and physiological structures of the nervesystem with the superior psychological functions, in addition to pergoing through social aspects, which are considered as a great influence on the formation of language and thought, since the development of the embryo until early childhood.

Thus, enabling the education and health professional to perform better in their actions and neuropsychopedagógicas interventions. It's worth pointing out. that there is no specific structure of evaluation and identification, although it is of great importance to have some strategy that can enable the paths to the construction of a greater neuropsychopedagogical contribution.

In this context, the educator and any other specialized professional must have a "higher examination of life, in order to be able to transform education into a creation of life" (VYGOSTKY, 2003/1926, p. 301). For this new educational and life perspective open up unlimited possibilities "for the creation of life in its infinite diversity. Making the contribution of neuropsychopedagogy beyond the narrow limits of tarefto personal and personal life, and can transform a true creator of the future." (p.304). Where the goal for the education and development of the child is no longer aimed at adapting to the existing environment, but the creation of an individual who looks beyond the environment that surrounds him. 


\title{
2.3. The Contributions of neuropsychopedagogue in the School Context: in the Rehabilitation of Children with Learning Deficit in Basic Education
}

Based on this new specialization that comes to contribute significantly to the developmentand learning of children mainly in basic education, when we talk about the school context and rehabilitation of children with learning disabilities we can mention that: according to the theory vygotskyana,

\begin{abstract}
Education never begins on an empty ground, never begins to forge totally new reactions [..]. In this sense, education is the re-education of what has already been accomplished. Therefore, the first requirement of any education is the absolutely necessary knowledge of the forms of behavior inherited, because the personal sphere of experience will be lifted up on them. And here comes with special force the knowledge of individual differences. (VYGOSTKY, 2003/1926, p.283)
\end{abstract}

According to VYGOSTKY, the human condition, with the value ofdiversity, the understanding of this diversity and, at the same time, of singularity, should be the greatest object of all teaching, because it would enable the recognition of the holistic human being, in its cosmic, physical, biological and cultural dimensions.

PARA METRING and SAMPAIO (2019) education, since its first

stages, should turn to the formation of critical and reflective individuals, with the ability to understand oneanother and others. Thus, the relationship of the child with the educational space and with the authors who are part of it would enable experiences that would facilitate this understanding and recognize oneanother as part of humanity and to recognize the diversityfor cultural age that surrounds it (MORIN, 2000).

Thinking about the complexity of these spaces can be the starting point for the articulation of these numerous components that involve the learning teaching process, less than contradictory. The great challenge of neuropsychopedagogical action in the teaching process learning in the rehabilitation of children in early childhood education, without perceiving theinnumerations involved in this process, aspects that go beyond the individual, but that, at the same time, at the same time, they encompass unique, singular life stories, but stories moderated by diverse contexts.

the school and its professionals should take into view that their role is to 
teach, but not only in the sense of transmitting content, but seeking to integrate knowledge with a view to mediating the subjective construction of individuals, providing them with resources to perform and interpret the world, through their own singular histories (HERNANDEZ, 1998 and ASPILICUETA; CRUZ, 2012) apud (SAMPAIO, 2019, p.97). For this we need to know:

[...] what is needed to participate in today's society andask yourself: what is important to learn? What techniques, skills and abilities are required now? What values should be set up? "Add to these, the questions: what is the role of the school in the face of new educational demands? What relationship between Educationand Technology? What knowledge and competence are necessary for the citizen of the 2ist century." (SBC, 2007, apud SOARES and SEVERINO, 2014).

In this way need to participate in a society becomes inevitable and this participation will require us a training that allows us to develop and exercise our skills and abilities constituted of values that includes the school to meet the new demands and transmit the new content and enable the student to make the taking of the educational and technological knowledge understanding that we can no longer ignore the need to appropriate knowledge.

The contribution of neuropsychopedgogia in the educational process is of

fundamental importance, understanding that rehabilitation needs to be a clear process and understood by all who are involved. School and education professionals, especially those in rehabilitation who work with atividades, exercises, tasks and occupations used as an intervention resource. Therefore, the intervention of the neuropsychopedagogue and his student is a continuous search for "learning in the dimension of manization, to feel, think, exercise and act with the emotionalbrain for decisionmaking". Relvas (2009), such interventions can be constructed from the need for rehabilitation of each child, because within what we consider necessary to rehabilitate learning mainly with children with learning disabilities.

Neuropsychopedagogy gathered all aspects addressed throughout its learning to exercise in an essential way to indicatethe path to be taken to contribute rehabilitation of children with learning disabilities. So far, the path of this study has led to consolidation in the multidisciplinary field of knowledge of the professional's performance in an educational practice that 
will favor a good quality of life and better understanding of the learning process.

\subsection{METHODOLOGY}

To achieve the objectives of this study, it was necessary a bibliographic research of qualitative nature that was based on some theorists that deal with this theme: The Contributions of neuropsychopedagogue in the School Context: in the Rehabilitationof Childrenwith Learning Disabilities in Basic Education.

What for Lakatos (1992, p. 44) bibliographic research allows us to understand that if on the one hand the resolution of a problem can be obtained through it, on the other hand, both laboratory and field research (direct guidance) require as premisethe survey of the study of the question that is proposed to analyze and present possible solucões.

Search for terms/keywords; Apprenticeship. Deficit. Rehabilitation. through the bibliographic survey, MeSH (Medical Subject Headings)from the portal of the U.S. National Library of Medicine (BNM) and DeCS (Descriptors in Health Science).

They were used to match the descriptors and terms used to track publications. Additionally, libraries, books and academic papers will be consulted as potential bibliographic references.

After the analysis of the bibliographic material, only the articles of greatest relevance to the proposed objective were selected, which would meetthe inclusioncriteria: national articles, from 2000 to the present day, some articles were used available in the databases.

\section{RESULTS AND DISCUSSION}

The findings about the Contributions of the Neuropsychopedagogist in the School Context: in the Rehabilitation of Children with Learning Disabilities in Basic Education. It involved the understanding of learning deficit; Why Children Do Not Learn; The Importance and Contribution of Neuroscience in the Formation and Practice of Neuropsychopedagogue and The Contributions of Neuropsychopedagogue in the School Context: in the Rehabilitation of Children with Learning Disabilities in Basic Education. 
in this context, the presente study had a qualitative approach of exploratory character where the placement of some theorists strengthened the analysis and discussion that led to the build of this result.

The learning deficit for (MERCH apud MALUF) is "The child's learning process is understood as a multi-causal,comprehensive process, involving components of various axes of structuring: affective, cognitive, motor, social, economic, and political". This means that, when we know the apprenticeag in as a process consisting of several factors, not being able to accept a single cause as a determinant for the difficulties related to it. SAMPAIO (2014).

So when we ask why children don't learn? It may be linked to several factors, aspects and physical, economic, social, emotional affective, cultural, political, cognitive, psychological, neurological and family situations.

The Importance and Contribution of Neuroscience in the Formation and Practice of Neuropsychopedagogue places that educators and any other specialized professional must have a "higher examination of life, in order to transform education into a creation of life" (VYGOSTKY, 2003/1926, p. 301). Only by taking these paths will your contribution have meaning in your neuropsychopedagogical practice.

The Contributions of neuropsychopedagogue in the School Context: in the Rehabilitation of Children with Learning Deficit in Basic Education. For this, it is necessary that the neuropsychopedagogue can harmoniously establish knowledge and its neural connections and synapses of the quality of capitation, selection, memorization, storage, retention, evocation, and later transmiti the information in order to build knowledge in the student and make it able to produce and reflect with the learned object.

\section{FINAL CONSIDERATIONS}

The neuropsychopedagogy professional when appropriating the knowledge of neurosciences will have a theoretical support that will allow him to understand theaspectsof cognitive functions such as: attention, memory, tactile kinesthesis, motor, superior to the example of language, planning, judgment, etc.. Verbal and not verbais. 
consider that their training is continuous since every day the challenges are also renewed and increasingly need greater understandings to meet the growing demand in this universe of globalization and technological development. Understanding that his contribution has an interdisciplinary and transdisciplinary nature, understanding that the neuropsychopedagogist must par excellence an eternal apprentice as well as a critical-reflective researcher of his own praxis.

Still in this line the neuropsychopedagogue should consider that his technical-scientific improvement about neurological, psychiatric and psychological disorders of the neurolearner will strengthen his performance. For Beauclair (2014, p. 35) apud (Santos 2015) "the neuropsychopedagogue must have the will to expand his theoretical references, studying fields of knowledge different from those who are already accustomed in his professional trajectory and expanding their epistemological curiosity."

\section{REFERÊNCIAS}

ALBUQUERQUE, Rosangela Nieto. Neuropsychopedagogy and psychopathologies: knowing the brain and understanding learning. First. Ed. Recife: Tarcísio Pereira, 2014.

BRAZIL. Law of Guidelines and Bases of National Education. Law No. 9,394 of December 20, 1996. Brasília: Federal Senate, Subsecretariat of Technical Editions, 2002. Available in: http://www.planalto.gov.br. Access: 03 Mar. 2020, ı0:ooh.

BRAZIL. National Curriculum Parameters: Portugueselanguage / ministry of education secretariat of elementary education. 3rd edition, 2001. Available in: http://www.portaldomec.gov.br. Access on: 03 Mar. 2020, 2:00 p.m.

BEAUCLAIR, J. Neuropsychopedagogy: insertions in the present, utopias and future desires. Ed. Rio de Janeiro: Essence all,20I4.

HART, A.L; BERVIAN, P.A. Scientific methodology. Second. Ed. São Paulo: MC Graw Hill do Brasil, Artmed, 1983.

Farrell, Michael. Moderate, severe and profound learning difficulties: teacher's guide. Ist ed. São Paulo: Artmed, 2008.

FONSECA, Vitor(Role of cognitive, conactive and executive functions in learning: a neuropsychopedagogical approach. Portugal: Psychopedagogical magazine, 2014. 
JOSÉ and COELHO. Learning Problems. Elizabeth of The Assumption Joseph, Maria Teresa Coelho. 2nd ed. São Paulo: Attica, 2002.

Lakatos, Maria Eva. Methodology of Scientific Work. Second. Ed. São Paulo: Atlas, 20io.

METRING, Roberte and SAMPAIO, Simaia . Neuropsychopedagogy and Learning. Second. Ed. Rio de Janeiro: Wak,2019.

MORIN, Edgard. The Seven Knowledge Needed for the Education of the Future. Second. Ed. São Paulo: Cortez/UNESCO 2000.

OLIVEIRA, Nathália, NEUROPSYCHOPEDAGOGY - I received my first patient, and now? Scientific Article-Rio de Janeiro, 20r6. Available in: 〈http://www.núcleodoconhecimento.com.br $\rangle$. Access on 02 Apr,2020 to I2h.

RELVAS, Marta Pires, Que Cérebro é Esse Que Chegou A Escola: the neuroscientific bases of learning. Ed. Rio de Janeiro: Wak,2017.

RELVAS, Marta Pires. Neuroscience and learning disorders: the multiple efficiencies for inclusive education. Ed. Rio de Janeiro: Wak, 2015.

RELVAS, Marta Pires, Neuroscience and Education. First. Ed. Rio de Janeiro: Wak,2009.

SAMPAIO, Simaia. Learning difficulties : psychopedagogy in the relationship of the subject, family and school. Ed. Rio de Janeiro: Wak, 2017.

SAMPAIO, Simaia; FREITAS, Ivana Braga. Learning Disorders and Difficulties: understanding students with special educational needs better. 2nd ed. Rio de Janeiro: Wak, 20I4.

SOARES, M. \& SEVERINO, A. J. Projetos Pedagogical from a transdisciplinary perspective of learning. v. 16, n.2, p. 269-281. São Paulo: Quaestio, 2014.

SANTOS, Lucilia da Silva, The Performance of the Neuropsychopedagogist In the Fight against School Failure. Available from:〈http://www.portaleducacao.com.br $>$. Access: 30 Mar, 2020 to 14:00.

TOPCZEWSKI, open up. Learning and Your Disabilities How to Deal. First. Ed. São Paulo: Casa do Psicólogo, 2000.

VYGOTSKY, Lev s. The Social Formation of Mind : The development of Higher Psychological Processes. Organizers Michael Cole ... (et al.). 4th ed. São Paulo: Martins Fontes, 2003.

WEISS, Maria Lúcia Lemme; WEISS, Alba. Overcoming School Learning Difficulties. 2nd ed. Rio de Janeiro: Wak, 2009. 